\title{
Dimethoate のイエバエにたいする毒性と 湿度および溶媒の関係 ${ }^{1}$
}

Effect of humidity and solvent on the toxicity of dimethoate against the common house fly

長沢純夫柴 三 千 代2)
Sumio Nagasawa and Michiyo Shiba

Dimethoate は $80^{\circ} \mathrm{C}$ において $7 \%$ 程度水に可溶であ る。これは虫体が湿潤な状態におかれた場合, 乾燥した 環境条件下に打汀るよりもdimethoate はより多く体内に 吸収され，ひいてはその致死率もたかめられるであろう 々想像される。 また油もある程度虫体を湿潤な状態にて もつ上に役立ち, dimethoateの有効度に影響するものと かんがえられる. 本報においてはこの問題にかんしてお こなつた小実験の結果をのべたい，本文に入るに先だち 供試昆虫の飼育に御尽力いただいた伏見主子嬢に謝意を 表する.

\section{実験材料および方法}

供試昆虫：いわゆる高柣系と称せられるイエバエ (Musca domestica vicina Macq.) の, 羽化後 $4 \sim 5$ 日 目の雌成虫をこの実験にもちいた．これらの幼虫期の飼 育は, 常法の豆腐粕培基により, 成虫期の慨に法砂糖と 水をあたえた。

供試薬剤 : dimethoate：O,O-dimethyl-S-(N-methyl carbamoylmethyl) phosphorodithioate は実験室でメ夕 ノールで再結精製した m.p. 51-2の試料で，これをア セトンで表 1 にしめす 3 段階の濃度に稀釈してもちい た。さらに油の影響をみるために，ゴマ油をアセトンに $2 \%$ 加用，これをもちいて同様に 3 段階の濃度に薬液を 稀釈調製した。

実験方法：前のふたつの報告と同様 Finney（1946） によつてのべられた解析方法をそのまま適用することを 目的に，その論著にならつてつぎの様な計画でおこなわ れた，すなわちまず，供試昆虫は約40匹を，直径 $9 \mathrm{~cm}$, 高さ $7 \mathrm{~cm}$ のガラス容器にいれ, サランの網蓋をかぶせ, その上から脱脂綿にひたした稀釈牛乳をあたえた。こう

1）殺虫剂の生物試験にかんする研究，第 45 報 Studies on the biological assay of insecticides. $\mathrm{XLV}$

2）イハラ農薬研究所

Ihara Agricultural Chemicals Institute, Shimizu
してわけられた供試個体群をふたつにして，そのひとつ を湿度約 $100 \%$ の，他のひとつを約 70\% の環境条件下 に24時間放置した．24時間後にさきに調製した薬液を， 炭酸ガスで軽く麻酔したイエバエの胸背部に，micrometer syringe で滴下処理した. 処理したものはあたらし く餌をあたえて，高低両湿度環境条件下におき，24時間 後にその生死を記録した。なお別に溶媒のみの処理によ る対照区をもうけ，その斃死率をもとめた。すなわち㭗 液処理前および後に, 高, 低両湿度環境条件下におくこ とによつて，4つの組合せができ，さらに溶媒にゴマ油

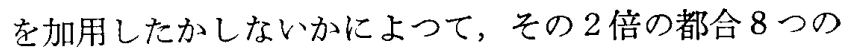

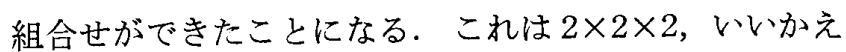
れば $2^{3} の$ factorial system の配置にあり，薬剂処理前 に放置した関係湿度, 処理後のそれ，およびゴマ油の 3 要因は，それぞれふたつの相対する条件，すなわちはじ めのふたつの要因については, $100 \%$ と $70 \%$, 後のゴマ油 については加用，無加用の相互の条件をそなえている. Finney（1946）のそれにならつて，関係湿度 100\%の条 件下においたものに W (Wet)，70\%においたものに D (Dry), ゴマ油の加用に O (Oil) のコードレターをあた え，それぞれ 8 コの組合せを表 1 にしめす様に区別し た.たとえば W.D.O. としるしたものは，薬剤処理前 24 時間, 関係湿度 $100 \%$ の条件下におき，ゴマ油を加用 したアセトンで稀䣋した dimethoate を処理した後，今 度は $70 \%$ の関係湿度条件下に 24 時間おいたものである ことを意味する．この実験は 1964 年 4 月 2 日〜16 日に わたる期間にくりかえしおこなわれたもので,都合 4,676 匹の個体がもちいられた。飼育, 実験すべて温度 $25^{\circ} \mathrm{C}$ の恒温室においておこなつた。

\section{実験結果と考察}

実験結果を表示すると表1のごとくである.ここでし めした致死率は，それぞれの対照区における生存率をも つて Abbott の式により補正した数值である. 表 1 にし 
Table 1. Results of toxicity tests of dimethoate on the common housefly, Musca domestica vicina Macq.

\begin{tabular}{|c|c|c|c|c|c|c|c|c|}
\hline \multirow{2}{*}{$\begin{array}{l}\text { Dosage } \\
(\mu \mathrm{g} / \text { 우 })\end{array}$} & \multicolumn{2}{|c|}{ D. D. } & \multicolumn{2}{|c|}{ W. D. } & \multicolumn{2}{|c|}{ D. W. } & \multicolumn{2}{|c|}{ W. W. } \\
\hline & $\begin{array}{c}\text { Number of } \\
\text { flies used }\end{array}$ & $\begin{array}{l}\text { Per cent } \\
\text { mortality }\end{array}$ & $\begin{array}{l}\text { Number of } \\
\text { flies used }\end{array}$ & $\begin{array}{l}\text { Per cent } \\
\text { mortality }\end{array}$ & $\begin{array}{l}\text { Number of } \\
\text { flies used }\end{array}$ & $\begin{array}{l}\text { Per cent } \\
\text { mortality }\end{array}$ & $\begin{array}{l}\text { Number of } \\
\text { flies used }\end{array}$ & $\begin{array}{l}\text { Per cent } \\
\text { mortality }\end{array}$ \\
\hline 0.00195 & 159 & 9.6 & 160 & 5.0 & 159 & 3.0 & 160 & 10.0 \\
\hline 0.0039 & 159 & 31.0 & 159 & 34.3 & 155 & 43.5 & 160 & 51.6 \\
\hline 0.0078 & 159 & 93.5 & 159 & 91.5 & 159 & 96.9 & 160 & 96.0 \\
\hline Control & 120 & 3.3 & 120 & 3.3 & 121 & 19.0 & 120 & 8.3 \\
\hline \multirow{2}{*}{$\begin{array}{l}\text { Dosage } \\
(\mu \mathrm{g} / \text { 우 })\end{array}$} & \multicolumn{2}{|c|}{ D. D. O. } & \multicolumn{2}{|c|}{ W. D. O. } & \multicolumn{2}{|c|}{ D. W. O. } & \multicolumn{2}{|c|}{ W. W. O. } \\
\hline & $\begin{array}{l}\text { Number of } \\
\text { flies used }\end{array}$ & $\begin{array}{l}\text { Per cent } \\
\text { mortality }\end{array}$ & $\begin{array}{l}\text { Number of } \\
\text { flies used }\end{array}$ & $\begin{array}{l}\text { Per cent } \\
\text { mortality }\end{array}$ & $\begin{array}{l}\text { Number of } \\
\text { flies used }\end{array}$ & $\begin{array}{l}\text { Per cent } \\
\text { mortality }\end{array}$ & $\begin{array}{l}\text { Number of } \\
\text { flies used }\end{array}$ & $\begin{array}{l}\text { Per cent } \\
\text { mortality }\end{array}$ \\
\hline 0.00195 & 160 & 6.1 & 159 & 2.9 & 162 & 9.2 & 171 & 10.6 \\
\hline 0.0039 & 160 & 42.0 & 160 & 39.0 & 160 & 54.1 & 159 & 58.6 \\
\hline 0.0078 & 120 & 88.7 & 159 & 96.7 & 120 & 94.6 & 120 & 96.1 \\
\hline Control & 118 & 4.2 & 119 & 6.7 & 120 & 7.5 & 120 & 15.0 \\
\hline
\end{tabular}

Table 2. Summary of calculations for estimation of eight regression lines (All doses were multiplied by 100 in order to avoid negative values of $x$ )

\begin{tabular}{|c|c|c|c|c|c|c|c|}
\hline Series & $\bar{x}$ & $\bar{y}$ & $\Sigma w$ & {$\left[w x^{2}\right]$} & {$[w x y]$} & {$\left[w y^{2}\right]$} & {$[w x y]^{2} /\left[w x^{2}\right]$} \\
\hline D. D. & 0.60005 & 4.83646 & 181.77 & 7.28813 & 33.70890 & 173.05545 & 155.90967 \\
\hline W. D. & 0.61632 & 4.84245 & 181.01 & 7.25458 & 36.95623 & 191.30727 & 188.26217 \\
\hline D. W. & 0.61494 & 5.03734 & 143.39 & 4.10434 & 25.54259 & 159.95204 & 158.95952 \\
\hline W. W. & 0.56675 & 5.00299 & 181.93 & 7.27749 & 35.99773 & 179.83443 & 178.06092 \\
\hline D. D. O. & 0.60873 & 4.89044 & 186.94 & 7.79104 & 35.61843 & 162.88249 & 162.83738 \\
\hline W. D. O. & 0.62259 & 4.99882 & 150.94 & 4.43890 & 27.88102 & 177.36639 & 175.12250 \\
\hline D. W. O. & 0.56437 & 4.98559 & 183.07 & 7.22348 & 34.97873 & 169.44149 & 169.37979 \\
\hline W. W. O. & 0.53136 & 4.93349 & 178.79 & 6.51023 & 32.28175 & 160.12630 & 160.07290 \\
\hline Total & - & - & 1387.84 & 51.88819 & 262.96538 & 1373.96586 & 1348.60485 \\
\hline
\end{tabular}

Table 3. Test of heterogeneity and parallelism of regressions

\begin{tabular}{ccccc}
\hline Nature of variation & $\begin{array}{c}\text { Degrees of } \\
\text { freedom }\end{array}$ & Sum of squares & Mean square \\
\hline Common slope & 1 & $\Sigma^{2}[w x y] / \Sigma\left[w x^{2}\right]=1332.68844$ & $A=2.27$ \\
Departure from parallelism & 7 & $\Sigma\left([w x y]^{2} /\left[w x^{2}\right]\right)$ & $\frac{15.91641}{1348.60485}$ & \\
Separate slope & 8 & $\Sigma \chi^{2}$ & $\frac{25.36101}{1373.96586}$ & $s^{2}=3.17$ \\
Residual heterogeneity & 8 & $\Sigma\left[w y^{2}\right]$ &
\end{tabular}

めした処理薬量 $X$ を対数変換したときに生するる負数を なくし，以後の計算操作を簡便にするために，まずこれ を1,000 倍した上でその対数をとり，これに対応する致 死率 $Y$ をプロビット $y$ に変換し, 常法により両者の関 係を一次の回帰方程式にもとめた．表 2 はその要約で表 3 はこれらの8 回帰直線の異質性と平行性を検定した結 果である．異質性の $\chi^{2}$ は 25.36 で有意であるが，この 平均平方は，平行性にかんする平均平方にくらべて大き
く, $A / s^{2}=0.72$ は有意水準 0.05 における $F$ の值 3.73 よりも小で,これらの回帰直線は互に平行関係にあると みなしてさしつかえない，それ故，共通の角係数 $b_{c}=\Sigma$ $[w x y] / \Sigma\left[w x^{2}\right]=5.06792$ をもちいて，これと表 2 にし めした $\bar{x}, \bar{y}$ とから 8 本の平行な回帰直線の方程式 $Y$ $=\bar{y}+b_{c}(x-\bar{x})$ をもとめ, $Y=5$ とおけば対数単位で しめした中央致死薬量 $\log \mathrm{LD}_{50}$ の算定が可能である. $2^{3}$ の factorial system の計画にしたがつておこなわれ 
Table 4. Calculations for main effects and interactions

\begin{tabular}{lcrrrr}
\hline Series & $\bar{y}$ & \multicolumn{1}{c}{$(1)$} & \multicolumn{1}{c}{ (2) } & \multicolumn{1}{c}{$T_{y}$} & (3) for $\bar{x}, T_{x}$ \\
\hline D. D. & 4.837 & 9.680 & 19.720 & 39.529 & 4.730 \\
W. D. & 4.843 & 10.040 & 19.809 & 0.029 & -0.051 \\
D. W. & 5.037 & 9.889 & -0.028 & 0.391 & -0.176 \\
W. W. & 5.003 & 9.920 & 0.057 & -0.201 & -0.111 \\
D. D. O. & 4.890 & 0.006 & 0.360 & 0.089 & -0.066 \\
W. D. O. & 4.999 & -0.034 & 0.031 & 0.085 & 0.013 \\
D. W. O. & 4.986 & 0.109 & -0.040 & -0.329 & -0.108 \\
W. W. O. & 4.934 & -0.052 & -0.161 & -0.121 & 0.017
\end{tabular}

た実験結果の解析方法については，Yates（1937）によつ て論じられ，Finney（1946）によつてもその適用例がし めされた。 そして長沢・柴 (1964) むさきにDDT, naled のイエバエにたいする毒性と温度，および溶媒の 関係を解析するにあたつてこれを応用した。 ところで Finney，長沢・柴は，各要因の主効果および交互作用の 程度を算定するにあたつては，8つの回帰方程式によつ てもとめたそれぞれの $\log \mathrm{LD}_{50}$ と，表 2 にしめした $\bar{x}$ とをむちいたが，この $\log \mathrm{LD}_{50}$ のかわりに表 $2 の \bar{y}$ もちいても，算定のための式を多少変えることにより，当 然同じ結論に達するはずである。 Finney 後年, この $\bar{y}$ と $\bar{x}$ とから, 各要因の主効果および交互作用の程度 を算定する方法をしめした，すなわち表 4 の第 2 欄にし めした数值は，表 2 のをそのままうつしたものであ る.（1），(2)，（3）欄の数值のもとめ方は, 先報と全く 同じで，第 1 欄の最初の 4 つの数值は，前欄の数值をそ れぞれ順次にふたつずつたした結果であり，つぎの 40 の数值は，順次ふたつずつの下の数值から上の数值をひ いた差である、第 (2)，(3) 欄の数值も同様にしてもと

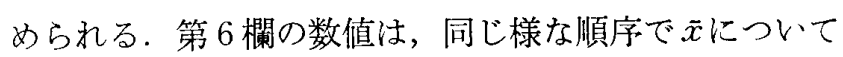
計算された $\bar{y} の(3)$ に相当するものである.

$\bar{x}$ および $\bar{y}$ の (3) 欄の数值をそれぞれ $T_{x}, T_{y}$ とす ると，表 4 の最初の闌の $T_{x}, T_{y}$ は，それぞれ 8 コの $\bar{x}, \bar{y}$ の合計で，特に意義をもつものではない，のこる 7 コの対応する $T_{x}, T_{y}$ から，

$$
M=-\frac{1}{4}\left(T_{x}-T_{y} / b\right)
$$

の式によつて順次計算した結果が，それぞれ表 5 にしる
した様な各要因の主効果, および交互作用の程度をしぬ。 寸数值である。これらの variance 注

$$
V(M)=\frac{1.96}{16 b_{c}^{2}}\left\{\Sigma\left(\frac{1}{\Sigma w}\right)+\frac{\left(4 M+T_{x}\right)^{2}}{\Sigma\left[w x^{2}\right]}\right\}
$$

の式によつてもとめられ，表 5 の標準偏差は，その平方 根である.

表 5 にみる様に，多湿状態においた方があきらかに dimethoate の有効度は高まり，ことに処理後多湿状態 においた場合，その值は有意である。またゴマ油を溶媒 に加用することにより, dimethoateの有效度はある程度 䯩まるが，有意といいうるほどのものではないことがわ かる. 表 $5 の 6$ 行目の $M$ と 2 行目の $M$ とをたした数 值

$$
0.063+0.011=0.073=\log 1.18
$$

は，溶媒にゴマ油を加用して処理したものを乾燥状態に おいた場合と，多湿状態においた場合とを比較したとき 後者の有效度の増大する程度をしめすものである，その 差

$$
0.063-0.011=0.052=\log 1.13
$$

は，ゴマ油を加用しないときのおなじ増大の程度をしめ すものである。表 6 はこらした関係を簡単なひとつの表 としてまとめたものである．処理前多湿の環境条件下に おいた場合の影響は，乾燥した環境条件下においた場合 にくらべて，平均してわずか $3 \%$ 有効度がたかまるだけ でさらにこれを処理後乾燥状態においたときと，多湿な 環境条件下に㧍いたときにわけて考えると，前者では 1 \%有効度がおとり，後者では $8 \%$ たかまる，そしてこれ をゴマ油を加用しない場合と加用した場合とにわけて考

Table 5. Summary of main effects and interactions expressed as relative potencies

\begin{tabular}{llrc}
\hline \hline \multicolumn{1}{c}{ Effect } & $M$ & Relative potency \\
\hline 1. Wet versus dry before treatment & $0.014 \pm 0.01489$ & 1.03 \\
2. Wet versus dry after treatment & $0.063 \pm 0.01491$ & 1.16 \\
3. Interaction of 1 and 2 & $0.018 \pm 0.01490$ & 1.04 \\
4. Soy bean oil & $0.021 \pm 0.01489$ & 1.05 \\
5. Interaction of 1 and 4 & $0.001 \pm 0.01489$ & 1.00 \\
6. Interaction of 2 and 4 & $0.011 \pm 0.01491$ & 1.03 \\
7. Interaction of 1,2 and 4 & $-0.010 \pm 0.01490$ & 0.98
\end{tabular}


Table 6. Estimated relative dosage values (measured on logarithmic scale)

\begin{tabular}{|c|c|c|c|c|c|c|c|}
\hline \multirow{2}{*}{ Relative dosage value for } & \multirow{2}{*}{ Mean } & \multicolumn{2}{|c|}{$\begin{array}{c}\text { Storage before } \\
\text { treatment }\end{array}$} & \multicolumn{2}{|c|}{$\begin{array}{c}\text { Storage after } \\
\text { treatment }\end{array}$} & \multicolumn{2}{|c|}{ Soy bean oil } \\
\hline & & Dry & Wet & Dry & Wet & Absent & Present \\
\hline $\begin{array}{l}\text { Wet instead of dry storage } \\
\text { before treatment }\end{array}$ & 0.014 & - & - & -0.004 & 0.032 & 0.013 & 0.015 \\
\hline $\begin{array}{l}\text { Wet instead of dry storage } \\
\text { after treatment }\end{array}$ & 0.063 & 0.042 & 0.084 & - & - & 0.052 & 0.074 \\
\hline $\begin{array}{l}\text { Addition of soy bean } \\
\text { oil to acetone }\end{array}$ & 0.021 & 0.020 & 0.022 & 0.010 & 0.032 & - & - \\
\hline
\end{tabular}

Table 7. Estimated relative potencies

\begin{tabular}{|c|c|c|c|c|c|c|c|}
\hline \multirow{2}{*}{ Relative dosage value for } & \multirow{2}{*}{ Mean } & \multicolumn{2}{|c|}{$\begin{array}{c}\text { Storage before } \\
\text { treatment }\end{array}$} & \multicolumn{2}{|c|}{$\begin{array}{l}\text { Storage after } \\
\text { treatment }\end{array}$} & \multicolumn{2}{|c|}{ Soy bean oil } \\
\hline & & Dry & Wet & Dry & Wet & Absent & Present \\
\hline $\begin{array}{l}\text { Wet instead of dry storage } \\
\text { before treatment }\end{array}$ & 1.03 & - & - & 0.99 & 1.08 & 1.03 & 1.04 \\
\hline $\begin{array}{l}\text { Wet instead of dry storage } \\
\text { after treatment }\end{array}$ & 1.16 & 1.10 & 1.21 & - & - & 1.13 & 1.19 \\
\hline $\begin{array}{l}\text { Addition of soy bean } \\
\text { oil to acetone }\end{array}$ & 1.05 & 1.05 & 1.05 & 1.02 & 1.08 & - & - \\
\hline
\end{tabular}

えると，それぞれ $13 \%$ ，および $15 \%$ の有効度の増大が あつたといいらる．２段目は処理後の湿度の影響，3段 目はゴマ油を溶媒に加用することの影響をしめすもので ある。

殺虫剤の有効度と湿度の関係については, 寸でに先学 者によつて種々研究されているが，これらは主に残溜毒 性と湿度の関係が実験され論じられているものである。

Hadaway \& Barlow (1957) は種々の被験物体に残溜す る殺虫剂に，虫体が接触し体内にとりいれられるまでの 湿度の影響恃大きいが，虫体に摂取されてから後の影響 はさして大きいものでないことをのべており， Kalkat et $a l$. (1961) は多湿の環境条件下においては，殺虫剂 の volatility がたかまり, 燻蒸効果が増大し, 高い殺虫 率がえられることをしるしている，才なわち残溜毒性と 湿度の関係が論ぜられる場合は，毒物に虫体が曝露され て摂取するまでの pre-treatment period の湿度が大きく 左右することがしめされている. しかし本論におけるご とく，主に毒物が搨取されてから後の吸収と湿度との関 係を論ずる場合は，処理前のそれよりも処理後の放置湿 度条件の方がより大きく有効度に左右すると考えること は難くなく，本実験の結果もこれを証明しえたというこ とができよう。

\section{摘要}

$2^{3}$ の factorial system の実験計画にもとづいて, dimethoate のイエバェにたいする䓯性と，湿度および溶 媒の関係を究明した. 羽化後 $4 \sim 5$ 日のイエバェの雌を
薬剤処理前の 24 時間を，関係湿度 $100 \%$ と $70 \%$ のふ つのことなつた環境条件下においた後, アセトンでとか した dimethoate およびゴマ油を $2 \%$ 加用したアセトン を溶媒とするそれを滴下法によつて処理した．処理した 個体は，さらに 24 時間 $100 \%$ および $70 \%$ の条件下にお いた後, その生死を判別した. $2^{3}$ すなわち 8 つの組合せ についてえられた, 濃度一致死率回帰直線のもつ $\bar{y}, \bar{x}$ に もとついて，これらの要因の相対力価を算定した結果, 供試個体を多湿状態においた方が，あきらかに dimethoate の有効度はたかまり，ことに処理後多湿状態にお いた場合，その值は有意であつた。 またゴマ油を溶媒に 加用した場合, ある程度有効度は高まるが, その值は有 意ではなかつた。

\section{引用文献}

1) Finney, D. J. (1946) : The analysis of a factorial series of insecticide tests, Ann Appl. Biol., 33: 160-5. -2) Finney, D. J. (1952) : Probit analysis. 318pp. Cambridge Univ. Press, London. -3) Hadaway, A. B. \& Barlow, F. (1957): The influence of temperature and humidity upon the action of insecticides. I. During the post-treatment period. Ann. Trop. Med. Parasitol., 51 : 187-93. -4) Kalkat, G. S., Davidson, R. H. \& Brass, C. L. (1961) : The effect of controlled temperature and humidity on the residual life of certain insecticides. J. Econ. Entomol., $54:$ 1186-90. 一5) 長沢純夫, 柴三千代 : （1964） （1964）DDTのイエバェにたいする毒性と温度および 溶媒の関係. 応動昆, $8: 203-8$. 一6) 長沢純夫, 柴三 千代 (1964)：Naled のイエバエにたいする毒性と温度 
およ溶媒の関係. 防虫科学, 29: 一7) Yates, F. (1937): The design and analysis of factorial experiments. Tech. Commun. Bur. Soil. Sci., Harpendon. No. 35

\section{Summary}

Seven per cent of dimethoate is soluble in water at $80^{\circ} \mathrm{C}$. It is possible that the absorption and toxicity of dimethoate in insects are more influenced by the higher atomospheric humidity than by the lower atomospheric humidity. It is also thinkable that oil added to solvent is useful to maintain insects in wet condition. A $2^{3}$ factorial experiment on alternative storage conditions concerning the atomospheric humidity for insects before and after treatment and the adjuvant effect of soy bean oil to solvent in topical application was designed to test the toxicity of dimethoate against the common house fly, Musca domestica vicina Macquardt. The house flies were stored at either 70 or $100 \%$ relative humidity for 24 hours before treatment, and also at either 100 or $70 \%$ relative humidity for 24 hours after treatment. Soy bean oil was used as a 2 per cent $(\mathrm{v} / \mathrm{v})$ solution in acetone. The experimental data obtained (Table 1) were analysed by the method described by Finney (1952). As is seen in the estimated relative dosage values (Table 6) or relative potencies (Table 7), the effect of atomospheric humidity after treatment was the highest among the factors concerning to the absorption and toxicity of dimethoate against the house fly, and the adjuvant effect of soy bean oil was not significant. 